\title{
The Alternative Binary Geothermal Power-Plant Design to Utilize the Waste Heat in Lahendong Plant
}

\author{
Eli Kumolosari ${ }^{1}$, Bahrul Jalaali ${ }^{1, ~}{ }^{*}$, Kutut Suryopratomo ${ }^{2}$, Okto Dinaryanto ${ }^{1}$ \\ 1,3 Department of Mechanical Engineering, Sekolah Tinggi Teknologi Adisutjipto, Indonesia \\ ${ }^{2}$ Nuclear Engineering and Engineering Physics, Faculty of Engineering, Universitas Gadjah Mada, Indonesia \\ Email Corresponding: *Bahrul.jalaali@ mail.ugm.ac.id
}

Received : July 24, 2020 ; Accepted : August 14, 2020 ; Published : November 1, 2020

\begin{abstract}
The first geothermal binary system in Indonesia that has successfully implemented is a $500 \mathrm{~kW}$ binary system in Lahendong. Yet, there is still a plenty room of improvement for binary system development in Lahendong. This study aims to give an alternative design of the binary system by using an organic Rankine cycle. The investigations of thermodynamic analysis based on the law of thermodynamics, silica scaling analysis, and optimization of working fluid selection are presented. Flashing process from separator produces vapor and liquid-brine with mass flow rates $48.6 \mathrm{~kg} / \mathrm{s}$ and $173.6 \mathrm{~kg} / \mathrm{s}$ at separator pressure of $10.23 \mathrm{bar}$. Based on second law thermodynamics analysis, obtained the maximum useful energy from brine flow is $7.2 \mathrm{MW}$. Based on the simulation results, it is achieved that the potential power generated by waste heat from the Lahendong plant is $2.46 \mathrm{MW}$ with the net thermal and exergy efficiency by $11 \%$ and $34 \%$, respectively. Compared to the current operating binary system, still, much available energy needs to be harnessed in the future from the Lahendong plant.
\end{abstract}

Keyword: Geothermal, Binary Cycle, Organic Rankine Cycle

\section{ABSTRAK}

Sistem pembangkit panas bumi biner pertama di Indonesia yang telah berhasil diimplementasikan ialah sistem biner $500 \mathrm{~kW}$ di Lahendong. Namun, masih terdapat celah untuk meningkatkan pengembangan sistem biner di Lahendong. Kajian ini bertujuan untuk memberikan perancangan alternatif dari sistem biner dengan menggunakan siklus Rankine organik. Investigasi analisis termodinamika berbasis hukum termodinamika, analisis scaling silika dan optimisasi pemilihan fluida kerja akan disajikan. Proses flashing dari separator menghasilkan uap air dan brine-cair dengan laju alir massa 48,6kg/s dan 173,6kg/s serta tekanan separator 10,23 bar. Berbasis analisis hukum kedua termodinamika didapatkan energi berguna maksimal dari aliran brine sebesar 7,2MW. Berdasarkan hasil simulasi, didapatkan bahwa potensi daya yang dapat dibangkitkan dari panas buang di Lahendong sebesar 2,46MW dengan efisiensi termal dan eksergi bersih sebesar $11 \%$ dan 34\%. Dibandingkan dengan sistem biner yang telah beroperasi, masih terdapat banyak energi yang dapat diambil dalam pengembangan ke depan di pembangkit Lahendong.

Kata Kunci : Panas Bumi, Siklus Biner, Siklus Rankine Organik

\section{INTRODUCTION}

Indonesia, which located in the ring of fire region has as much as $40 \%$ of geothermal potential in the world by $28.91 \mathrm{GW}$ [1]. Geothermal systems in Indonesia is dominated by high temperature hydrothermal $\left(>225^{\circ} \mathrm{C}\right)$ with liquid dominated characteristic [2]. One of commercially operated geothermal power-plant (GPP) in Indonesia is Lahendong GPP owned by Pertamina Geothermal Energy (PGE) Company. Lahendong GPP unit III is supplied from 5 well cluster that has characteristic of the acid reservoir and contains high silica concentration. Wellhead pressure and temperature of the reservoir are 13.4 bar and $250^{\circ} \mathrm{C}$, respectively. Flashing process from separator produces vapor and liquid (brine) with mass flow rates $48.6 \mathrm{~kg} / \mathrm{s}$ and 173.6 $\mathrm{kg} / \mathrm{s}$ at separator pressure of 10.23 bar. Brine that is usually re-injected into the soil still has a high temperature by $180^{\circ} \mathrm{C}[3,4]$ which is has a high content of energy that can be utilized again. The alternative way to utilize thermal energy from geothermal's brine for electric generation purpose is binary power-plant (PP) based on organic Rankine cycle (ORC). The first ORC system in Indonesia that has successfully been implemented is a $500 \mathrm{~kW}$ binary system in Lahendong. However, there is still a plenty room of improvement in Lahendong binary system design.

Quoilin (2013) was specifically studied the aspect of ORC system that was able to generate energy from a low-temperature source. Organic fluid will be used as working fluid in ORC. Furthermore, the ORC system was often applied for small scale PP. Despite it has the same working principle as the conventional Rankine cycle, ORC does not necessary to provide boiler as it is replaced by the heat exchanger. Working fluid will experience phase change from liquid to vapor by extracting the heat from heat sources using the heat exchanger. ORC PP has widely been applied in many ways such as a binary system of biomass PP, 
concentrated solar power, waste heat recovery, and heat recovery as well [6]. Wakana (2013) was investigated the successfully operated binary system for geothermal in Burundi, Africa. It was noted that observation of geological and geochemistry aspect should be underlined in the design of geothermal binary system. A simple scheme of the binary system is shown in Fig.1 [7].

ORC geothermal involves the analysis of silica scaling that often becomes the problem in the geothermal system. Moreover, the selection of working fluid needs to be considered as well. Type of working fluid should be determined by considering the thermodynamics properties of the working fluid. Masheiti (2011) was investigated the performance of the ORC system in Waddad, Libya, by comparing the working fluid performance of R134a and R245fa. In terms of performance at fixed output of 350kW, R134a needs pumping power higher than R245fa. In line with that, the rate of cooling water of R134a was also higher than R245fa system. Thermodynamically, R245fa is better than R134a [8]. Nugroho (2015) evaluated the ORC system for geothermal by modifying the working fluid. Nugroho states that applying regenerator can optimize the power output [3]. Frick (2015) proposed the design of intermediary HE for a binary system. As shown in Fig.2, primary HE is used to harvest the energy from brine to the evaporator in the main binary system. Brine that contains many minerals and chemical content should not be in direct contact with the main system evaporator to prevent the direct damage [10]. Based on previous studies, this paper aims to adopt the design by utilize the intermediary HE. In this paper, intermediary HE will be written in common term as thermal oil HE.

Agani et al. (2015) discussed the obstacle of the binary system in geothermal, especially in Ulubelu site. The main constraints of binary geothermal PP were the reinjected temperature and silica scaling. First, the reinjection temperature will not be allowed to be low because it can affect the reservoir temperature so that the productivity of the geothermal system will be decreasing. The reinjection well should be placed far away from the main wellhead. Second, at low-temperature silica scaling within the pipe will be formed and blocked the the pipe which is affecting pipe's leakage. Silica formation prevention can be done in several ways. The acidity of brine flow needs to be controlled at neither lower than $\mathrm{pH} 5$ nor above $\mathrm{pH} 9$ to delay the silica formation. Unfortunately, $\mathrm{pH}$ treatment has the disadvantages at the high cost and lowering the pipe endurance because of its corrosion effect. Silica scaling analysis by using silica scaling index is capable of determining the optimal condition in the scaling prevention [9].

This study aims to present an alternative design of the binary system in Lahendong PP. Thermodynamics analysis, silica scaling prevention, and working fluid selection become the main concern of this paper. The comparison with other binary cycles is also presented to give a picture of the current binary system reliability. The calculation is performed using the Cycle Tempo. As cited by Heberle (2015), He simulated PP model using Cycle Tempo for Kirchstockach PP in Germany. Actual data validated the model, and it affirms that Cycle Tempo was able to reproduce real PP in well agreement result [11]. The rest of the paper is organized as follows, Sec. II, we show the methods in the designing of the binary cycle. Sec. III is about result and discussion. We sum up all the finding and give a conclusion in Sec. III.

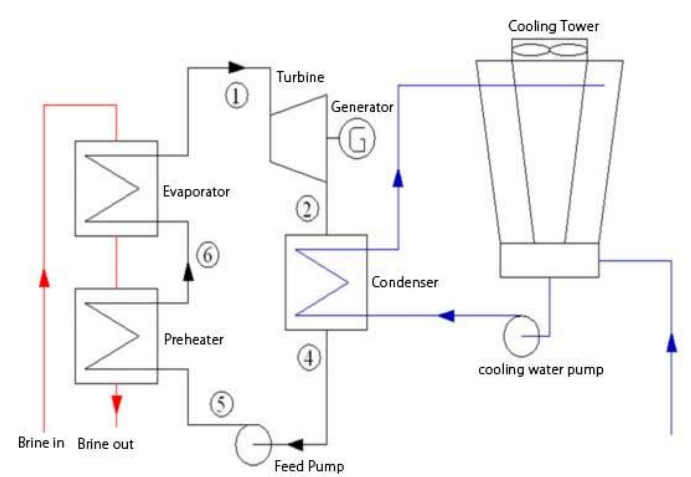

Figure 1. Simplified scheme of ORC power plant [7].

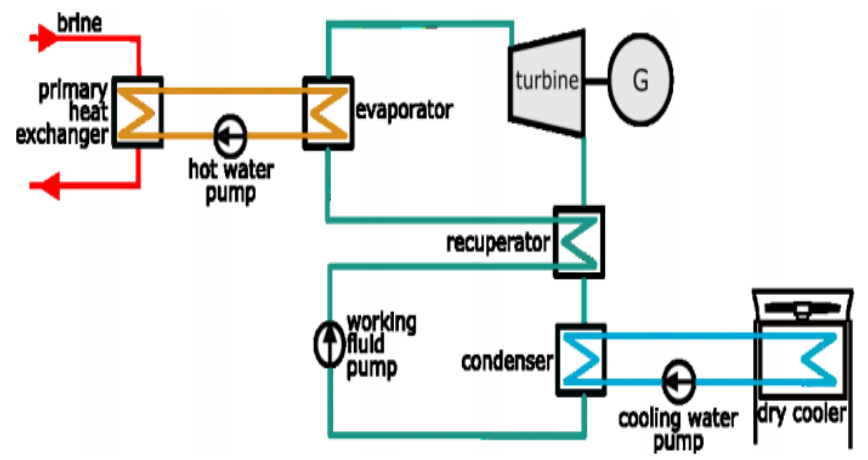

Figure 2. ORC system with intermediary HE [9].

\section{METHODS}

\subsection{Thermodynamics Analysis}

Thermodynamics analysis is performed to evaluate and investigate the preliminary binary cycle design. Equation of mass and energy balance as following the thermodynamics law shown in Eq.1 and Eq.2. 
$\frac{\text { dmsystem }}{\mathrm{dt}}$ is the rate of mass change inside the investigated system. Extended of energy equation is shown in Eq.3.

$$
\begin{gathered}
\dot{\boldsymbol{m}}_{\mathrm{in}}-\dot{\boldsymbol{m}}_{\mathrm{out}}=\frac{d m_{\text {system }}}{d t} \\
\dot{\boldsymbol{E}}_{\mathrm{in}}-\dot{\boldsymbol{E}}_{\text {out }}=\frac{d E_{\text {system }}}{d t}
\end{gathered}
$$

$$
\dot{Q}_{i n}+\dot{W}_{i n}+\Sigma_{i n} \dot{m}\left(h+\frac{V^{2}}{2}+g z\right)=\dot{Q}_{o u t}+\dot{W}_{o u t}+\Sigma_{o u t} \dot{m}\left(h+\frac{V^{2}}{2}+g z\right)
$$

Where :

$$
\begin{array}{llcc}
\dot{\mathrm{Q}} & : \text { Heat }(\mathrm{kJ} / \mathrm{s}) & \mathrm{V} & : \text { velocity }(\mathrm{m} / \mathrm{s}) \\
\dot{\mathrm{W}} & : \text { Work }(\mathrm{kJ} / \mathrm{s}) & \mathrm{g} & : \text { gravity acceleration }\left(\mathrm{m} / \mathrm{s}^{2}\right) \\
\mathrm{h} & : \text { specific enthalpy }(\mathrm{kJ} / \mathrm{kg}) & \mathrm{Z} & : \text { elevation }(\mathrm{m})
\end{array}
$$

Thermodynamics first law states the quantity of energy. Actual system is not only determined by the quantity of energy but also is the quality [12]. Second law analysis is performed to show the quality and analysis of the potential energy of geothermal's brine. Quality of energy is represented by the entropy. Moreover, maximum work potential is defined as exergy or availability analysis. Entropy balance shows in Eq.4. Exergy of the system divided into heat, work, and mass flow. The exergy analysis is written in Eq. 4, Eq.5, Eq.6, Eq. 7 and Eq.8. Exergy can be destroyed as well during the process and it is in line with the rise of entropy generation (Eq.9). Exergy balance is shown in Eq.10.

$$
\Delta S_{s y s}=S_{1}-S_{2}=\int_{Q_{1}}^{Q_{2}} \frac{\delta Q}{T}+S_{g e n}
$$

Exergy of heat

$$
\begin{gathered}
X_{\text {heat }}=\left(1-\frac{T_{0}}{T}\right) Q \\
X_{\text {work }}=W-\left[P_{0}\left(V_{2}-V_{1}\right)\right] \\
X_{\text {mass }}=m \cdot \psi
\end{gathered}
$$

Exergy of mass

$$
\psi=\left(h-h_{0}\right)-T_{0}\left(s-s_{0}\right)+\frac{v^{2}}{2}+g z
$$

$$
\begin{gathered}
X_{\text {destroyed }}=T_{0} . S_{\text {gen }} \geq 0 \\
\dot{X}_{\text {in }}-\dot{X}_{\text {out }}-\dot{X}_{\text {destroyed }}=\frac{d X}{d t}
\end{gathered}
$$

\subsection{Organic Rankine Cycle}

The ORC system are often used for the binary system. ORC has the same principle as conventional vapor Rankine system [13]. Precisely, ORC binary system for geothermal's brine must underline the working fluid selection and the silica scaling treatment.

\subsection{Working Fluid Selection}

Working fluid selection in ORC system has a significant impact on the PP performance. Lots of organic fluid are available for ORC working fluid, but it is limited within the working fluid criteria. It should be noted that organic fluids are made of chemical content that is dangerous on the open circumstances. Working fluid criteria are namely the safety factor, environmentally hazardous, flammability, toxicity, ozone depleted potential, and global warming potential. Thermodynamics aspect is considered to obtain the optimum PP performance [13].

\subsection{Silica Scaling}

Silica scaling phenomena is frequently found in Indonesia geothermal site. Silica precipitation is formed when the concentration of silica in brine flow is above the silica dissolves. Precipitation will affect the process devices as it is able to make the blockage inside the pipe. Silica scaling effect is the function of acidity $(\mathrm{pH})$, salinity and temperature [13]. Since acidity and salinity treatment are difficult and costly, currently the most effective way to prevent silica scaling is the temperature treatment. In terms of temperature, the temperature of brine is adjusted above the silica formation condition. Saturated silica concentration can be analyzed using silica saturation index (SSI) as an empirical approximation. Silica began to precipitate when the value of SSI $>1$. SSI formula is shown in Eq. 11.

$$
S S I=\frac{S_{i}}{S_{i i}}
$$

Where $\mathrm{Si}$ is the silica concentration each ppm in geothermal brine after the flashing process (Eq.12). Qc is quartz concentration as a function of reservoir temperature (Eq. 13). Whereas $\mathrm{x}$ is a vapor fraction in the 
flashing process. Sii (Eq.14) represents the silica amorph or dissolved silica in ppm at brine as a function of brine reinjection temperature (T)(Kelvin) using the empirical formula of Fournier and Marshall [13].

$$
\begin{aligned}
& S_{i}=\frac{Q_{c}(t)}{1-x} \\
& Q_{c}(t)=41.598+(0.23932) t_{\text {res }} \\
& -(0.011172) t_{\text {res }}^{2} \\
& +(1.1713) 10^{-4} t_{\text {res }}{ }^{3} \\
& -(1.9708) 10^{-7} t_{\text {res }}{ }^{4} \\
& S_{i i}=10^{\left[-6.116+(0.01625) T-(1.758) 10^{-5} T^{2}+(5.257) 10^{-9} T^{3}\right]}
\end{aligned}
$$

\subsection{Data and Assumptions}

In this paper, data were obtained from [3] as shown in Table 1 and it will be used as simulation data. Calculation of design is carrying out by using Cycle Tempo. The assumptions and data input are shown in Table 2. The isentropic efficiency of pump, turbine and $\mathrm{HE}$ are assumed to $85 \%, 80 \%$ and $100 \%$, respectively. Cycle Tempo aims to calculate the value of the relevant mass and energy flow in the system [14]. Iteration and matrix operation are the general principle of Cycle Tempo calculation.

Table 1. Brine data of Lahendong III

\begin{tabular}{clcc}
\hline No & \multicolumn{1}{c}{ Description } & Value & Unit \\
\hline 1 & Brine mass flow rate & 173.56 & {$[\mathrm{~kg} / \mathrm{s}]$} \\
2 & Brine temperature from separator & 180.8 & {$\left[{ }^{\circ} \mathrm{C}\right]$} \\
3 & Brine enthalpy & 768.41 & {$[\mathrm{~kJ} / \mathrm{kg}]$} \\
4 & Separator pressure & 10.23 & {$[\mathrm{Bar}]$} \\
5 & Environment temperature & 26 & {$\left[{ }^{\circ} \mathrm{C}\right]$} \\
6 & Reservoir temperature & 250 & {$\left[{ }^{\circ} \mathrm{C}\right]$} \\
7 & Atmospheric pressure & 1.013 & {$[\mathrm{Bar}]$} \\
\hline
\end{tabular}

Table 2: Additional Data for Simulation

\begin{tabular}{clcc}
\hline No & \multicolumn{1}{c}{ Description } & Value & Unit \\
\hline 1 & Brine reinjection temperature & 150 & {$\left[{ }^{\circ} \mathrm{C}\right]$} \\
2 & Brine pressure & 10.2 & {$[\mathrm{Bar}]$} \\
3 & Cooling water inlet temperature & 27 & {$\left[{ }^{\circ} \mathrm{C}\right]$} \\
4 & Cooling water outlet temperature & 37 & {$\left[{ }^{\circ} \mathrm{C}\right]$} \\
5 & Turbine inlet pressure & 13 & {$[\mathrm{Bar}]$} \\
6 & Turbine outlet pressure & 2.5 & {$[\mathrm{Bar}]$} \\
7 & Turbine inlet temperature & 102 & {$\left[{ }^{\circ} \mathrm{C}\right]$} \\
\hline
\end{tabular}

\section{RESULT AND DISCUSSION}

Silica precipitation is boarded within the pipe whenever brine's silica content at a certain temperature above the silica amorphs. Silica scaling increases significantly at $\mathrm{pH}$ 6-7 condition [13]. Unfortunately, chemical treatment was not practically easy to do since acidity of chemical treatment can affects the pipe corrosion. In this design, the silica prevention method uses temperature treatment. By using SSI, quartz plotted based on reservoir temperature at $250{ }^{\circ} \mathrm{C}$ shows in the blue line (Fig. 3). The green line presents the silica amorph concentration at a certain temperature. SSI equals to 1 as shown in yellow line is the saturated silica condition which is at $147^{\circ} \mathrm{C}$. In this case, silica scaling is formed while the brine temperature is below than $147^{\circ} \mathrm{C}$. Nevertheless, for this design, brine reinjection temperature sets to $150^{\circ} \mathrm{C}$ 
with SSI 0.97 . It is not only to prevent the scaling formation but also $150^{\circ} \mathrm{C}$ is chosen to obtain the optimum energy.

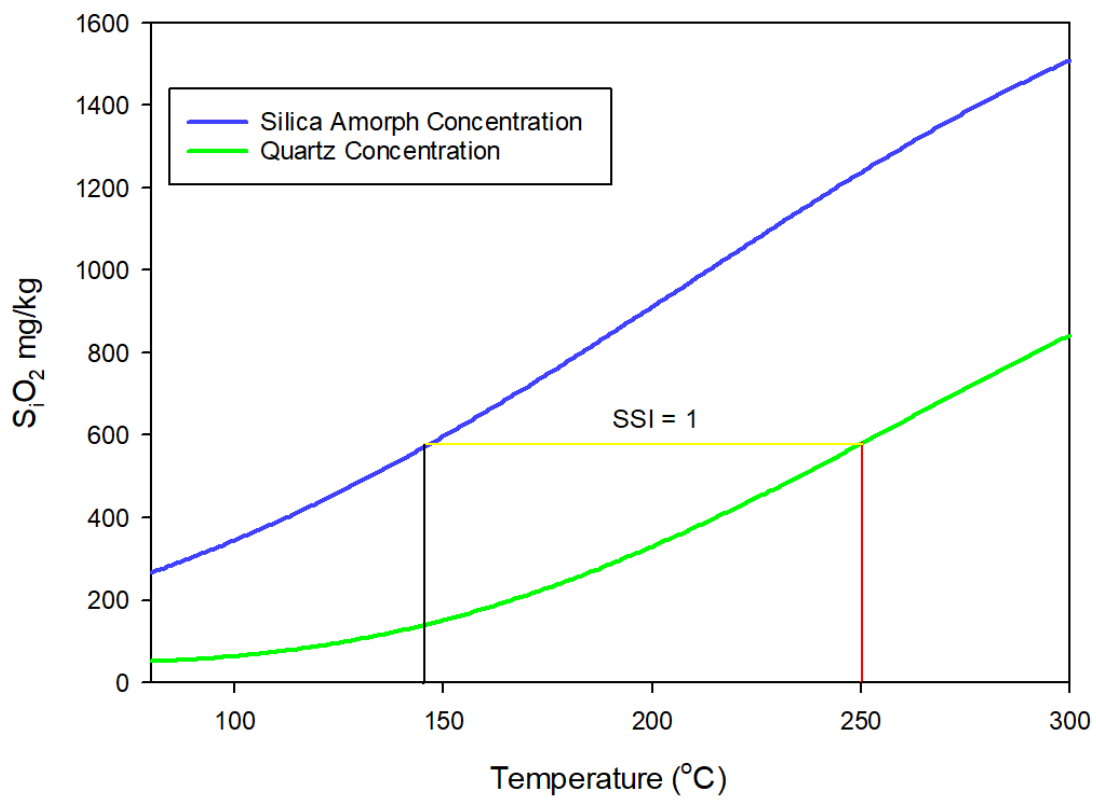

Figure 3. SSI analysis

ORC geothermal in this study uses R245fa as working fluid. Thermodynamically, R245fa has characteristic of isentropic fluid so that the droplet appearance inside the turbine can be denied. Isentropic properties of R245fa shows in Fig.4. If R245fa is in saturated condition and expanded under isentropic condition (point 1-3), R245fa will remain in the vapor phase (point 3). It will be the advantages when R245fa is adjusted into superheat condition. Amlaku et al (2010) affirm that ORC system under operating temperature above $160^{\circ} \mathrm{C}$, working fluid of R245fa has the better performance in terms of power generation output [15].

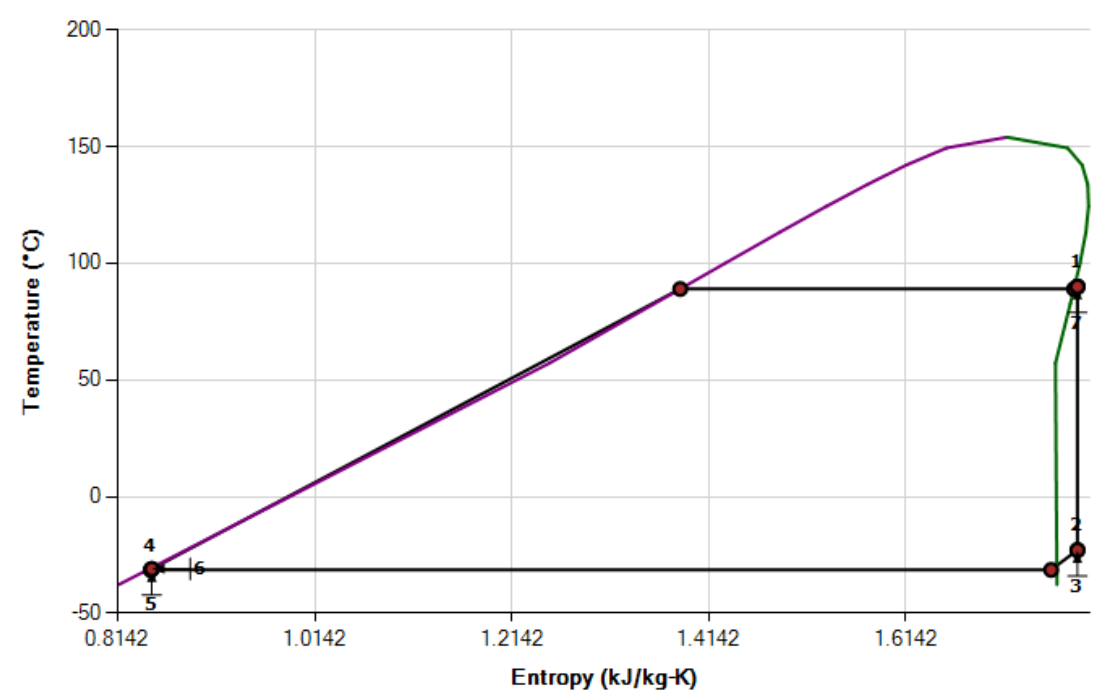

Figure 4. T-s diagram of R245fa in isentropic condition. 


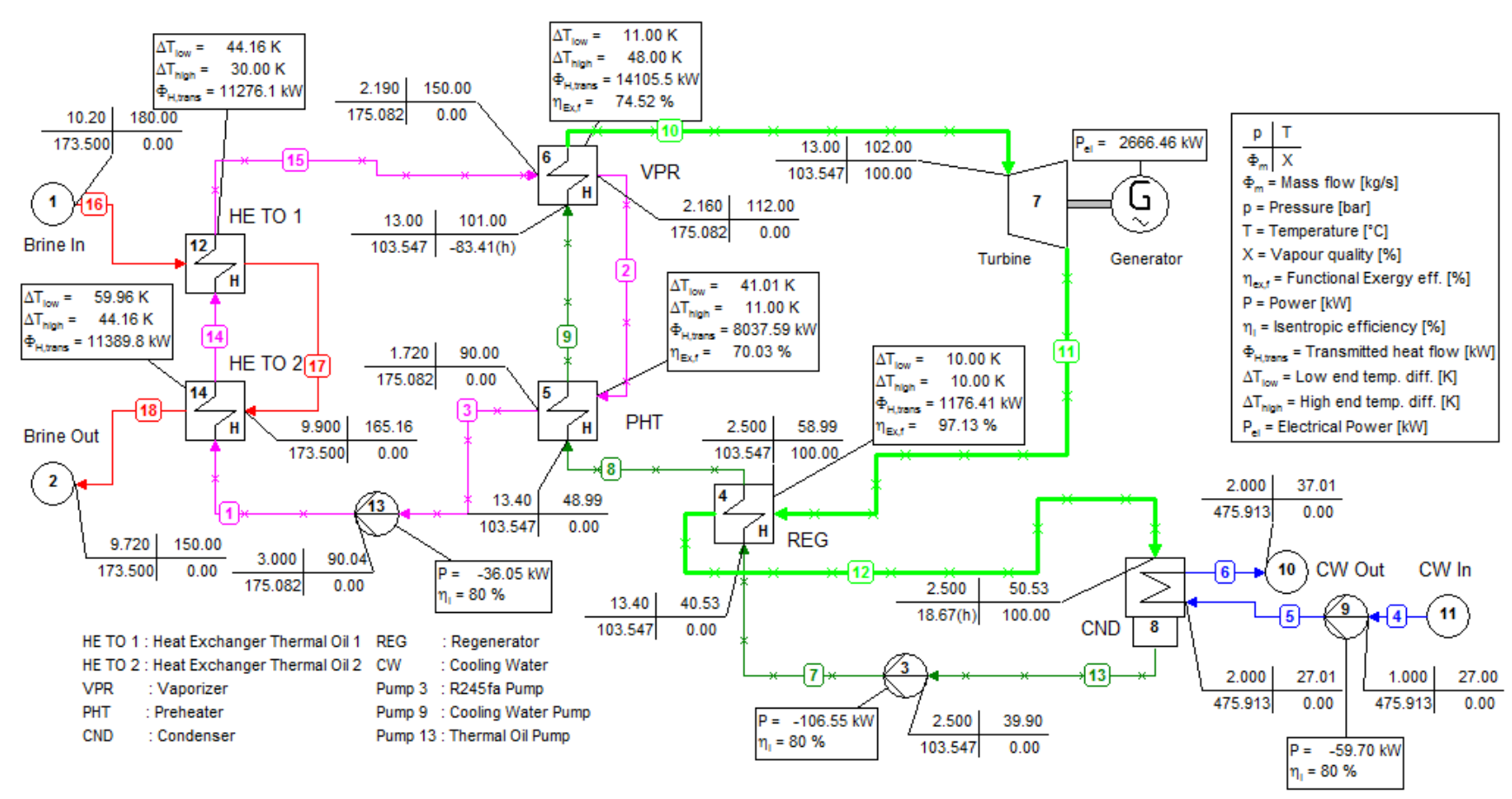

Figure 5. Binary system scheme

Moreover, ozone depleted potential (ODP) of R245fa is nearly 0. It is not a flammable fluid within the atmospheric condition and is not corrosive as well. The toxicity level of R245fa is B1 based on ASHRAE standard (number 34, 2013) which is explain that toxic content is low and safe for the open environment [16]. On the availability aspect, R245fa is already widely used by applied binary power plant, so it will not be an obstacle in terms of availability. Based on those conditions, in this paper, R245fa will be chosen as a working fluid in the binary system. In addition, intermediary HE uses downtherm $\mathbf{J}$ for its working fluid. It because downtherm $\mathbf{J}$ is commonly used and already reliable for intermediary HE.

The first law of thermodynamics is only stated about the energy content in the system. However, to determine the amount of useful energy, the second law analysis is used. Exergy analysis will be performed in between $180^{\circ} \mathrm{C}$ and $150^{\circ} \mathrm{C}$. Exergy calculation result shows in the Table 3 . From the exergy analysis, the maximum useful energy from brine flow is $7.2 \mathrm{MW}$. The value of useful energy states that binary system will only have the maximum capacity of 7.2MW. The first law analysis is also be done in order to analyze the thermal efficiency performance. The calculation of energy content in brine flow using the first law is shown in the Table 4. It is obtained that $173.5 \mathrm{~kg} / \mathrm{s}$ mass flow rate delivers the energy content as much as $22.7 \mathrm{MW}$. Moreover, due to the limitation of energy quality as states by the second law, the maximum useful energy is 7.2MW.

Table 3. Exergy calculation

\begin{tabular}{clll}
\hline No & & Parameter & Unit \\
\hline 1 & Exergy flow at $180^{\circ} \mathrm{C}$ & 22.2 & MW \\
2 & Exergy flow at $150^{\circ} \mathrm{C}$ & 15.1 & MW \\
3 & Exergy flow of brine & 7.2 & MW \\
\hline
\end{tabular}

Table 4. Energy quantity calculation

\begin{tabular}{clll}
\hline No & \multicolumn{1}{c}{ Parameter } & Value & Unit \\
\hline 1 & High temperature & 180 & ${ }^{\circ} \mathrm{C}$ \\
2 & Low temperature & 150 & ${ }^{\circ} \mathrm{C}$ \\
3 & Mass flow rate & 173.5 & $\mathrm{~kg} / \mathrm{s}$ \\
4 & Energy quantity & 22.7 & $\mathrm{MW}$ \\
\hline
\end{tabular}


The binary system scheme is presented in Fig.5. Based on the Cycle Tempo, the calculation results are shown in the Table 5. The total energy delivered by brine flow is enormous high at $22.7 \mathrm{MW}$. The total heat transfer area of $\mathrm{HE}$ will be huge as the consequence of the amount of energy. The serial sequence of 2 $\mathrm{HE}$ is presented to reduce the heat transfer load and to symmetrically divided the heat transfer area. The gross power of the current system is $2,666.5 \mathrm{~kW}$ or $2.67 \mathrm{MW}$. The gross system efficiency is $11.7 \%$. Furthermore, parasitic power in ORC system covers the power of mechanical devices namely the primary pump for $\mathrm{R} 245 \mathrm{fa}$, the secondary pump of thermal oil HE and cooling water pump. The total parasitic power is $202.3 \mathrm{~kW}$.

Table 5. Binary plant calculation result

\begin{tabular}{clll}
\hline No & \multicolumn{1}{c}{ Parameter } & Value & Unit \\
\hline 1 & Gross power & $2,666.5$ & {$[\mathrm{~kW}]$} \\
2 & Net power & $2,464.2$ & {$[\mathrm{~kW}]$} \\
& Parasitic power & & \\
& Cooling water pump & 59.7 & {$[\mathrm{~kW}]$} \\
3 & Working fluid pump & 106.6 & {$[\mathrm{~kW}]$} \\
& Thermal oil pump & 36.1 & {$[\mathrm{~kW}]$} \\
4 & Gross thermal efficiency & $11.7 \%$ & \\
5 & Net thermal efficiency & $11 \%$ & \\
6 & Exergy efficiency & $34 \%$ & \\
\hline
\end{tabular}

The appearance of parasitic power will decrease the system net power since it is the difference between gross power and parasitic power. Based on the calculation result is obtained the net power of the binary system is $2464.2 \mathrm{~kW}$. Calculation of net thermal efficiency obtained by $11 \%$. Net power also states as the product of exergy. Total availability is $7.2 \mathrm{MW}$ while the total useful energy is $2.464 \mathrm{MW}$. Based on the comparison, the exergy efficiency of the system is as much as $34 \%$. It means that from waste heat under $180^{\circ} \mathrm{C}$ operating condition only harvests the $34 \%$ of energy availability. These condition is limited by reinjection temperature by $150^{\circ} \mathrm{C}$ since the binary system is limited by silica formation. The rest $66 \%$ of unuseful energy is destroyed due to the fluid flow exchange or heat transfer. Based on that, the difference of $150^{\circ} \mathrm{C}$ and environment temperature is wasted as waste energy. Otherwise, exergy efficiency resulted in this system is the optimum amount of energy can be utilized for a binary system. From the aforementioned explanation, it still needs to be solved the silica scaling problem so that the optimum energy can be obtained.

\section{CONCLUSION}

Based on the simulation results, it is obtained that the potential power generated by waste heat from Lahendong plant is $2.46 \mathrm{MW}$ with the net thermal and exergy efficiency by $11 \%$ and $34 \%$ respectively. Compared to the current operating binary system, with capacity $500 \mathrm{~kW}$, still much available energy needs to be harnessed in the future from the Lahendong plant waste heat.

\section{REFERENCES}

[1] ESDM, Statistik EBTKE 2014, Jakarta: Ministry of energy and mineral resources, 2014.

[2] N. Saptadji, "Sekilas Tentang Panas Bumi, Materi Panas Bumi," Institut Teknologi Bandung, Bandung.

[3] A. J. Nugroho, "Evaluation of Waste Brine Utilization from LHD Unit III for Electricity Generation in Lahendong Geothermal Field, Indonesia," in Geothermal Training Programme, Reykjavik, 2007.

[4] Breme, "A Hydrotectonic Model of a Geothermal Reservoir-A Study in Lahendong, Indonesia,". Elsevier, 2014.

[5] Detik (2019, January 21). Pertamina geothermal energy operasikan pltp binary cycle 500kW. Detik finance, retrieved from https://finance.detik.com/energi/d-4394447/pertamina-geothermal-energyoperasikan-pltp-binary-cycle-500-kw.

[6] S. Quoilin, "Techno-economic Survey of Organic Rankine Cycle (ORC) System," .Elsevier, 2013. 
[7] F. Wakana, "Preliminary Study of Binary PowerPlant Feasibility Comparing ORC and Kalina for Low-Temperature Resources in Rusizi Valley, Burundi," in Geothermal Training Programme, Reykjavik, 2013.

[8] S. Masheiti, B. Agnew and S. Walker, "An Evaluation of R134a and R245fa as the Working Fluid in an Organic Rankine Cycle Energized from a Low Temperature Geothermal Energy Resources," Journal of Energy and Power Engineering, vol. 5, no. David Publishing, pp. 392-402, 2011.

[9] M. Agani, "Opportunity and Barriers to Develop a Bottoming Unit by Utilizing Separated Hot Brine in Ulubelu, Indonesia," in Proceeding World Geothermal Congress, Melbourne, 2015.

[10] S. Frick, "Geothermal Binary Power Plant for Lahendong, Indonesia: A German-Indonesia Collaboration Project," in Proceeding World Geothermal Congress, Melbourne, 2015.

[11] F. Heberle, T. Jahrfeld and D. Brueggemann, "Thermodynamics Analysis of DOuble-Stage ORC for Low-Entalphy Sources Based on a Case Study for 5.5 MWe PowerPlant Kirchstockach (Germany)," in Proceeding World Geothermal Congress, Melbourne, 2015.

[12] Y. A. Cengel, Thermodynamics: An Engineering Approach 5th Ed., McGraw-Hill, 2006.

[13] R. DiPippo, Geothermal Powerplant: Principles, Applications, Case Studies and Environmental Impact 2nd de., Elsevier, 2007.

[14] T. Delft, "Cycle Tempo Reference Guide," TU Delft, Technical Notes.

[15] A. Amlaku and B. Olav, "Working Fluids for Low-Temperature Heat Source," Energy and Process Engineering, no. Elsevier, 2010.

[16] ASHRAE, "Designation and Safety Classification of Refrigerants. Ashrae Standard no 34," ASHRAE, 2013. 